\title{
Calorimetric Study of the Antibacterial Activity of Sodium n-Alkylsulfates on the Metabolism of Chromobacterium violaceum
}

\author{
C.E. Perles* and P.L.O. Volpe \\ Instituto de Química, Universidade Estadual de Campinas, CP 6154, 13084-971 Campinas - SP, Brazil
}

\begin{abstract}
A bioatividade de n-alquilsulfatos $\left(\mathrm{C}_{6}-\mathrm{C}_{10}\right.$ e $\left.\mathrm{C}_{12}\right)$ foi estudada utilizando-se calorimetria de fluxo em tempo real, para monitorar a resposta biológica (BR) produzida pelo metabolismo aeróbico da bactéria Chromobacterium violaceum. Todos os compostos apresentaram um comportamento linear no gráfico de BR vs. $\log$ (dose). Destes gráficos, foi calculado o valor de $(\text { dose })_{\max }$ para cada composto. O valor de (dose) ${ }_{\max }$, que está diretamente relacionado com a biotividade, permitiu uma boa correlação entre esta propriedade e a estrutura da molécula, mostrando que a atividade biológica é diretamente proporcional à lipofilicidade dos compostos.
\end{abstract}

The bioactivity of a series of sodium n-alkylsulfates $\left(\mathrm{C}_{6}-\mathrm{C}_{10}\right.$ and $\left.\mathrm{C}_{12}\right)$ was studied with flow calorimetry to follow in real time the calorimetric effect on the metabolic rate of the bacterium Chromobacterium violaceum. All the compounds showed a linear plot of the fraction of control metabolic heat rate against $\log$ (dose). From these plots the value of dose ${ }_{\max }$ (the dose producing zero metabolic heat rate) for each compound was evaluated. The value of dose ${ }_{\text {max }}$ is correlated with the chain length of the molecule, showing that their biological activity is directly proportional to the lipophilicity of the compound.

Keywords: flow calorimetry, Chromobacterium violaceum, homologous series, sodium n-alkylsulfates, bioactivity

\section{Introduction}

Cationic and anionic surfactants are compounds used extensively in products for hygiene and cleanliness. ${ }^{1}$ However, the bioactivity of these compounds, especially the anionic surfactants, are not satisfactorily described in the literature. Anionic surfactants are denaturating agents, the denaturation of proteins by sodium dodecylsulfate happens at millimolar concentrations. ${ }^{1}$ Many studies on the interaction of anionic surfactants with isolated biomolecules are described in the literature, however, little is known about the effects of of this class of surfactants on living cells.

According to Denyer ${ }^{2}$ the possible targets of action of the bactericidal agents are the cell wall, cytoplasmatic membrane and the cytoplasm. Jones and co-workers, ${ }^{3-5}$ Moosavi-Movahedi and co-workers, ${ }^{6,7}$ and Silva and Volpe, ${ }^{8}$ related studies about the action of a homologous series of sodium n-alkylsulfates on proteins and Jones ${ }^{9}$ published information on the surfactant effect on cellular membranes.

Globular proteins bind anionic surfactants, leading

* e-mail: ceperles@iqm.unicamp.br to denaturation of the protein. ${ }^{1,5,10}$ However, this information does not allow prediction of the activity that these compounds might have on a living cell, since bioactivity depends on complex interactions between the surfactant, the cellular membrane, extrinsic and intrinsic proteins, enzymes, organelles etc. The study of the effects of chemical compounds on living cells, in real time, became possible with the introduction of the flow calorimetric technique for the evaluation of the biological activity of drugs and monitoring of biological processes. ${ }^{11-13}$

Biological calorimetry for studies of Quantitative Structure-Activity Relationship (QSAR), was demonstrated by Beezer et al. ${ }^{14}$ Although the technique has good potential in the study of drug bioactivity on living systems, its use is still not widespread.

In this work, using flow calorimetry, the bioactivity of a series of sodium $n$-alkylsulfates $\left(\mathrm{C}_{6}-\mathrm{C}_{10}\right.$ and sodium dodecylsulfate (SDS)) was studied in C. violaceum, a gram-negative bacterium belonging to the class of flagellated bacilli and optional aerobiums. ${ }^{15}$ This microorganism is frequently found in soils and waters of tropical and subtropical areas. In Brazil, significant 
amounts of $C$. violaceum are found in the waters and on the margins of the Negro river. ${ }^{16}$

\section{Experimental}

\section{Reagents}

Glucose (Hoescht), anhydrous potassium phosphate monobasic and dibasic (Synth) were reagent grade. The sodium n-alkylsulfates used in this work were hexylsulfate $\left(\mathrm{C}_{6}\right)$, heptylsulfate $\left(\mathrm{C}_{7}\right)$, octylsulfate $\left(\mathrm{C}_{8}\right)$, nonylsulfate $\left(\mathrm{C}_{9}\right)$, decylsulfate $\left(\mathrm{C}_{10}\right)$ and dodecylsulfate $\left(\mathrm{C}_{12}\right)$ or SDS, all in the form of sodium salts. The $\mathrm{C}_{6}, \mathrm{C}_{7}, \mathrm{C}_{8}$ and $\mathrm{C}_{9}$ homologs were synthesized by mixing a solution of the appropriate long chain alcohol (Sigma) with chlorosulfonic acid (Vetec), in equimolar amounts in dry ethyl ether, followed by neutralization with $\mathrm{NaOH}$, according to the procedure described by Livingston et al. ${ }^{17}$ The synthesized surfactants were purified by recrystallization from isopropanol, as reported by Murphy and Taggart. ${ }^{18}$ Their structure and the purity were confirmed through ${ }^{1} \mathrm{H}$ NMR and infrared spectra. The $\mathrm{C}_{10}$ and $\mathrm{C}_{12}$ homologs were purchased from Sigma and Aldrich, respectively.

\section{Preparation of cells}

Chromobacterium violaceum was grown in $1.5 \mathrm{dm}^{3}$ flasks (B. Braun Biotech, Biostat B2) containing a sterilized culture medium of $\left(\mathrm{g} \mathrm{dm}^{-3}\right): 3.0$ of yeast extract, 7.5 of glucose and 7.5 bacteriologic peptone in distilled water, all in a sterilized PBS (phosphate buffered solution) composed of $\left(\mathrm{g} \mathrm{dm}^{-3}\right): 8.0$ of $\mathrm{NaCl} ; 0.20$ of $\mathrm{KCl} ; 1.15$ of $\mathrm{Na}_{2} \mathrm{HPO}_{4}$ and 0.20 of $\mathrm{KH}_{2} \mathrm{PO}_{4}$, at final $\mathrm{pH}$ 7.0.

The reactor flask was inoculated with $1.0 \mathrm{~cm}^{3}$ of cell suspension and incubated at $298 \mathrm{~K}$ on a rotatory shaker (200 rpm; Gallenkamp). After $14 \mathrm{~h}$ of incubation, the cells were separated from the culture medium by centrifugation at $4000 \mathrm{rpm}$ during $20 \mathrm{~min}$. The cells were washed three times by suspending in PBS solution and then centrifuged. After the last centrifugation, the cells were suspended again in $100 \mathrm{~cm}^{3}$ of PBS solution containing $10 \%$ dimethylsulfoxide and conditioned in $1.0 \mathrm{~cm}^{3}$ polypropylene ampoules (Corning).

The ampoules were inserted into a thin perforated styrofoam plate which was placed $8 \mathrm{~cm}$ above liquid nitrogen in an appropriate container. When the temperature in the control ampoule reached $200 \mathrm{~K}$ the ampoules were immersed in liquid nitrogen and stored in the cryogenic cylinder. ${ }^{19}$ A viable count, performed periodically, gave $1.3 \times 10^{10}$ cells $\mathrm{cm}^{-3}$. The cells were stored for up to 6 months and recovered with $95 \%$ viability.
Flow calorimetry and calorimetric curves

Antibacterial activities were determined with a Thermometric - TAM 2277 calorimeter, at 298.15 \pm 0.02 $\mathrm{K}$, fitted with a flow-through cell.

Before initiating the respiration experiment, a baseline was obtained by pumping the culture media through the flow cell without the microorganisms. When a stable baseline was established, an electrical calibration was performed to calibrate the heat rate scale. The composition of the culture media was $\left(\mathrm{g} \mathrm{dm}^{-3}\right): 1.80$ of glucose; 8.75 of $\mathrm{K}_{2} \mathrm{HPO}_{4} ; 1.88$ of $\mathrm{KH}_{2} \mathrm{PO}_{4}$, at $\mathrm{pH} 7$. Without the addition of the bioactive compounds (sodium $n$-alkylsulfates), this media was defined as a control preparation. During the course of this work, control curves were obtained periodically.

The inoculation of $C$. violaceum $\left(0.90 \mathrm{~cm}^{-3}\right.$ of the cell suspension) was done immediately after a reactivation process; defrosting the ampoule for $3 \mathrm{~min}$ in a water bath at $310 \mathrm{~K}$, followed by manual stirring for $20 \mathrm{~s}$. During the experiment, the bacterial suspension coming from a reactor was pumped into the flow-through cell $\left(30 \mathrm{~cm}^{3} \mathrm{~h}^{-1}\right)$ by an LKB 2132 peristaltic pump in a closed loop system. ${ }^{20}$

Any substance that modifies the metabolic process involved in cell growth and/or respiration will change the thermal power-time curve obtained from the calorimeter.

\section{Results and Discussion}

The control curve (control), corresponds to the maximum calorimetric signal generated by respiration of the microorganism in the experimental conditions in the absence of bioactive compounds. The maximum biological response $\left(\mathrm{BR}_{\max }\right)$ is the difference between the maximum of the calorimetric curve and the baseline.

Three control curves were performed to obtain the average $\mathrm{BR}_{\max } 57.6 \pm 1.0 \mu \mathrm{W}$. The small deviation $( \pm 1.7 \%)$ indicates that viability stayed constant during the period of this work. Thermal power-curves curves were obtained for each surfactant at various concentrations. Figure 1 shows the thermograms obtained for the $\mathrm{C}_{8}$ surfactant at the indicated concentrations.

Biological responses (BR) were obtained for each member of the homologous series and are shown in Table 1 . BR is obtained in the same way as $\mathrm{BR}_{\max }$, however $\mathrm{BR}$ is the percentage of $\mathrm{BR}$ in relation to the control. Table 1 also presents the correlation coefficients, slopes and intercepts of the plot $\log$ (dose) vs BR, as shown in Figure 2 for the $\mathrm{C}_{8}$ surfactant. The value of dose ${ }_{\text {max }}$ was estimated by extrapolation of the curve to $\mathrm{BR}=0$, the intercept. The maximum dose is the concentration of a compound that completely suppresses the calorimetric signal. ${ }^{21-23}$ The larger the value of dose $_{\max }$, the 


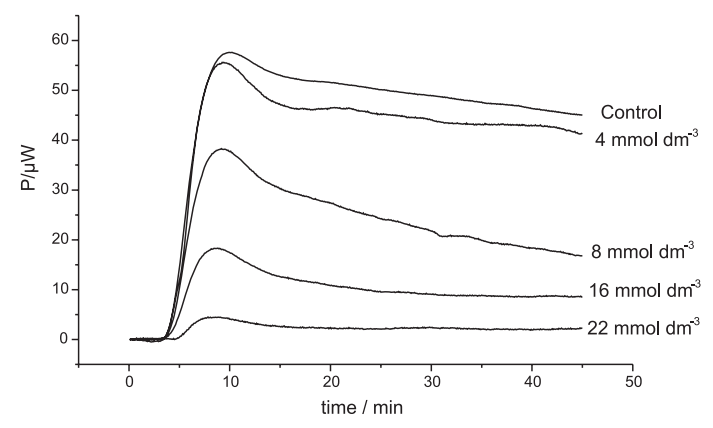

Figure 1. Power-time curve for the respiration of C. violaceum in different concentrations of n-octylsulfate.

smaller the bioactivity of the surfactant. For the $\mathrm{C}_{6}$ and $\mathrm{C}_{7}$ surfactants $\log$ (dose) is not correlated with BR. For $\mathrm{C}_{7}$, some concentrations resulted in $\mathrm{BR}>\mathrm{BR}_{\max }$, which could indicate activation or stress of respiration. Table 1 therefore only presents values of dose, $\log$ (dose) and BR for these surfactants.

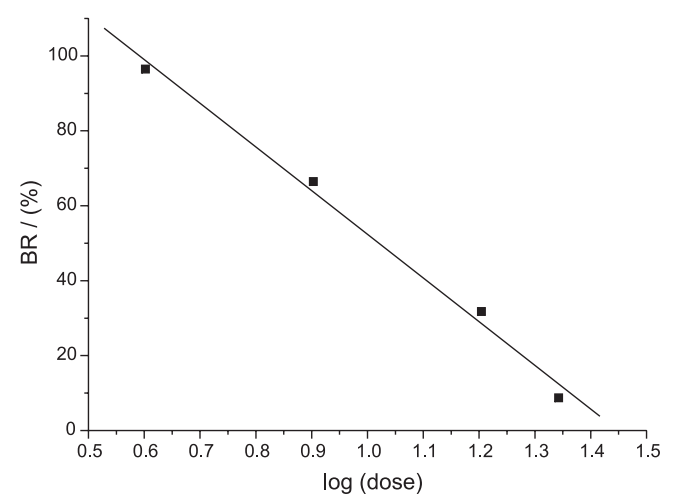

Figure 2. Biological response BR vs. $\log$ (dose) for n-octylsulfate.

The values of dose ${ }_{\text {max }}$ in Table 1 clearly show the effect of hydrophobicity on the toxicity of the sufactants. A plot of $\log (\text { dose })_{\max } v s$ carbon number in the surfactant molecule, Figure 3, yields a straight line (correlation coefficient, $r=0.9999)$. The toxicity is directly proportional to the number of $\mathrm{CH}_{x}$ groups in the structure of the hydrocarbon chain of the surfactant.

The data in Table 1 shows that the concentration of the most hydrophobic surfactant, sodium dodecylsulfate $\left(\mathrm{C}_{12}\right)$, necessary to inhibit bacterium respiration is 5 times smaller than $\mathrm{C}_{10}, 11$ times smaller than $\mathrm{C}_{9}$ and 28 times smaller than $\mathrm{C}_{8}$. For the compounds $\mathrm{C}_{6}$ and $\mathrm{C}_{7}$, $\mathrm{BR}$ is not related to $\log$ (dose).

Because $\log (\text { dose })_{\max }$ displays a linear relationship wich the number of carbon atoms in the alkyl chain, the same relationship is expected between $\log (\text { dose })_{\max }$ and the change in Gibbs energy for the transfer of these surfactants from aqueous to hydrophobic phase. Similar correlation was reported for m-alkoxyphenols. ${ }^{20,24}$

Calorimetry is a non-specific technique and does not permit infering the mechanism of action of these surfactants
Table 1. Values of dose, $\log ($ dose $), \log (\text { dose })_{\max }$, biological response and correlation coefficients, slopes and intercepts derived from plots of $\log$ (dose) vs. BR for sodium n-alkylsulfates

\begin{tabular}{|c|c|c|c|c|}
\hline Surfactant & $\begin{array}{c}\text { dose } \\
\left(\mathrm{mmol} \mathrm{dm}^{-3}\right)\end{array}$ & $\log ($ dose $)$ & & $\begin{array}{l}\text { BR } \\
(\%)\end{array}$ \\
\hline \multirow[t]{6}{*}{$\mathrm{C}_{6}$} & 70 & 1.8 & & 82.7 \\
\hline & 85 & 1.9 & & 93.3 \\
\hline & 95 & 2.0 & & 76.3 \\
\hline & \multicolumn{2}{|c|}{ corr.coef. } & - & \\
\hline & & & - & \\
\hline & \multicolumn{2}{|c|}{ intercept } & - & \\
\hline \multirow[t]{7}{*}{$\mathrm{C}_{7}$} & 12 & 1.1 & & 107.0 \\
\hline & 24 & 1.4 & & 95.9 \\
\hline & 30 & 1.5 & & 109.3 \\
\hline & 48 & 1.7 & & 51.2 \\
\hline & \multicolumn{2}{|c|}{ corr.coef. } & - & \\
\hline & & & - & \\
\hline & \multicolumn{2}{|c|}{ intercept } & - & \\
\hline \multirow[t]{7}{*}{$\mathrm{C}_{8}$} & 4 & 0.6 & & 96.5 \\
\hline & 8 & 0.9 & & 66.5 \\
\hline & 16 & 1.2 & & 31.8 \\
\hline & 22 & 1.3 & & 7.8 \\
\hline & \multicolumn{2}{|c|}{ corr.coef. } & 0.9958 & \\
\hline & & & -0.0085 & \\
\hline & \multicolumn{2}{|c|}{ intercept $=\log (\text { dose })_{\max }$} & 1.45 & \\
\hline \multirow[t]{7}{*}{$\mathrm{C}_{9}$} & 2 & 0.3 & & 91.0 \\
\hline & 4 & 0.6 & & 62.4 \\
\hline & 6 & 0.8 & & 43.2 \\
\hline & 8 & 0.9 & & 10.6 \\
\hline & \multicolumn{2}{|c|}{ coef corr.. } & 0.9727 & \\
\hline & & & -0.0080 & \\
\hline & \multicolumn{2}{|c|}{ intercept $=\log (\text { dose })_{\max }$} & 1.06 & \\
\hline \multirow[t]{9}{*}{$\mathrm{C}_{10}$} & 0.50 & -0.3 & & 82.8 \\
\hline & 0.75 & -0.1 & & 77.4 \\
\hline & 1 & 0 & & 56.8 \\
\hline & 2 & 0.3 & & 35.1 \\
\hline & 4 & 0.6 & & 8.2 \\
\hline & 5 & 0.7 & & 2.6 \\
\hline & \multicolumn{2}{|c|}{ corr.coef. } & 0.9942 & \\
\hline & & & -0.0119 & \\
\hline & \multicolumn{2}{|c|}{ intercept $=\log (\text { dose })_{\max }$} & 0.72 & \\
\hline \multirow[t]{7}{*}{$\mathrm{C}_{12}$} & 0.10 & -1.0 & & 86.8 \\
\hline & 0.25 & -0.6 & & 62.4 \\
\hline & 0.50 & -0.3 & & 22.5 \\
\hline & 0.75 & -0.1 & & 5.3 \\
\hline & \multicolumn{2}{|c|}{ corr.coef. } & 0.9862 & \\
\hline & \multicolumn{2}{|c|}{ slope } & -0.0105 & \\
\hline & \multicolumn{2}{|c|}{ intercept $=\log (\text { dose })_{m}$} & -0.04 & \\
\hline
\end{tabular}

against $C$. violaceum. The activity of these compounds on the respiration of $C$. violaceum cells may result from simultaneous effects on several cell functions. The relative importance of each effect may vary with the species of organism challenged. Observed effects in real time are an average of the whole population and do not necessarily reflect the sensitivity of all the cells. This is the basis by which surviving fractions in a treated population sometimes 


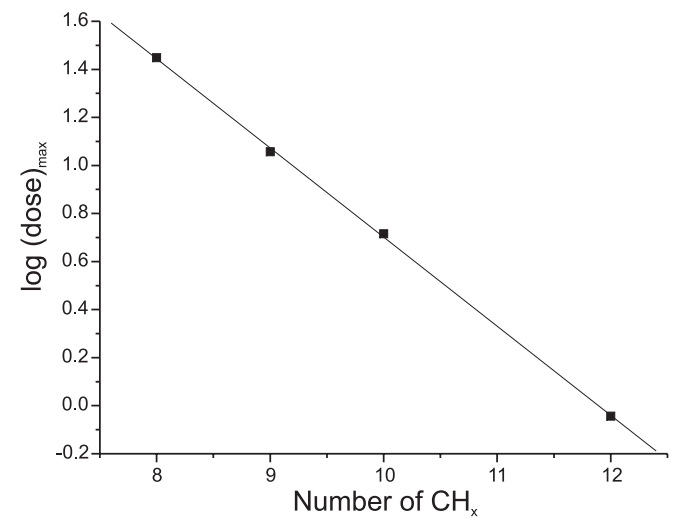

Figure 3. Variation of bioactivity within the homologous series of n-alkylsulfates.

remain, possibly to emerge more adequately equipped to deal with a subsequent biocide challenge. Mechanism of action studies usually only determine bulk population behavior. It should never be assumed that every bacterium in the population is suffering the same type and degree of damage at the same time. In this manner, flow calorimetry for monitoring the metabolism of cells in real time is a powerful complementary tool to QSAR studies. The correlation between a homologous series of compounds with $\mathrm{BR}$ is its formal basis.

\section{Conclusions}

Antibacterial effect of homologous anionic surfactants on the respiration of $C$. violaceum is directly dependent of their hydrocarbon chain length. These data are of significance to QSAR studies and to detergent and cosmetic research where molecule structure is related to biological response and to achievable solubility levels in the biophase.

$\mathrm{C}_{6}$ and $\mathrm{C}_{7}$ members of these series did not show a linear relationship between concentration and biological response, possibly due to their high solubility in the aqueous phase. The excellent linear relationship between $\log (\text { dose })_{\text {max }}$ and the number of $\mathrm{CH}_{\mathrm{x}}$ obtained through calorimetric measurements, allow us to restate the great potential of flow microcalorimetry for QSAR studies, showing advantages such as accuracy in a more realistic procedure, i.e., in real time and with living cells.

\section{Acknowledgments}

The authors wish to express their gratitude to Conselho Nacional de Desenvolvimento Científico e Tecnológico $(\mathrm{CNPq})$, and to Fundação de Amparo à Pesquisa do Estado de São Paulo (FAPESP) for their financial support.

\section{References}

1. Jones, M. N.; Int. J. Pharm. 1999, 177, 137.

2. Denyer, S. P.; Int. Biodeterior. 1990, 26, 89.

3. Jones, M.N.; Manley, P.; J. Chem. Soc. Faraday Trans. I 1980, $76,654$.

4. Jones, M.N.; Sarmiento, F.; Prieto, G.; J. Chem. Soc. Faraday Trans. 1992, 88, 1003.

5. Jones, M.N.; Gilhooly, E.M.; Nicholas, A.R.; J. Chem. Soc. Faraday Trans. 1992, 88, 2733.

6. Moosavi-Movahedi, A.A.; Razeghifard, M.R.; Thermochim. Acta 1991, 188, 183.

7. Moosavi-Movahedi, A.A.; Ghobadi, S.; Thermochim. Acta 1991, 189, 201

8. Silva Filho, E.A., Volpe, P.L.O.; Quím. Nova 1997, 20, 150.

9. Jones, M.N.; Int. J. Pharm. 1999, 177, 137.

10. Bartnik, F. G. In Anionic Surfactants - Biochemistry, Toxicology, Dermatology; Gloxhuber C.; Kunstler, K. eds., Marcel Dekker: New York, 1992, vol. 43, p.1-43

11. Beezer, A.E.; Biological Microcalorimetry, Academic Press: London,1980, p. 195-246.

12. Volpe P.L.O.; Quím. Nova 1993, 16, 49.

13. Beezer, A.E.; Volpe, P.L.O.; Gooch, C.A.; Hunter, W.H.; Anal. Proceed. 1986, 23, 399.

14. Beezer, A.E.; Volpe, P.L.O.; Gooch, C.A.; Hunter, W.H.; Miles, R.J.; Int. J. Pharm. 1986, 29, 237.

15. Durán, N.; Menck, C.F.M., Crit. Rev. Microbiol. 2001, 27, 121.

16. Caldas, L.R.; Pig, A.A.C.; Santos, S.M.; Tyrrel, R.M.; Proceedings of the International Symposium Current Topics in Radiolology and Photobiology, Academia Brasileira de Ciências: Rio de Janeiro, 1978, p.121.

17. Livingston, J.R.; Drogin, R.; Kelly, R.J.; Ind. Eng. Chem. Prod. Res. Develop. 1965, 4, 28.

18. Murphy, A.; Taggart, G.; Colloids Surf. A 2001, 180, 295.

19. Kirsop, B.E.; Snell, J.J.; Maintenance of Microorganisms, Academic Press: New York, 1991, p. 21-24, 175.

20. Volpe, P. L. O.; J. Braz. Chem. Soc. 1997, 8, 343.

21. Purcel, W. P.; Bass, G. E.; Clayton, J. M.; Strategy of Drug Design: The Guide of Biological Activity, John Wiley \& Sons: New York, 1973.

22. Sendel, J. K.; In Drug Design, E. J. Ariens, ed., Academic Press: New York - London, 1971, vol. 1, p. 343.

23. Hansch, C.; In Drug Design; Ariens, E. J. ed. Academic Press: New York, 1971, p. 271.

24. Beezer A. E.; Volpe, P. L. O.; Hunter, W. H.; J. Chem. Soc. Faraday Trans. I 1986, 82, 2863.

Received: March 8, 2005

Published on the web: August 24, 2005 